\title{
Harmonized dataset of ozone profiles from satellite limb and occultation measurements
}

\author{
V. F. Sofieva ${ }^{1}$, N. Rahpoe ${ }^{2}$, J. Tamminen ${ }^{1}$, E. Kyrölä ${ }^{1}$, N. Kalakoski ${ }^{1}$, M. Weber ${ }^{2}$, A. Rozanov ${ }^{2}$, \\ C. von Savigny ${ }^{3}$, A. Laeng ${ }^{4}$, T. von Clarmann ${ }^{4}$, G. Stiller ${ }^{4}$, S. Lossow ${ }^{4}$, D. Degenstein ${ }^{5}$, A. Bourassa ${ }^{5}$,

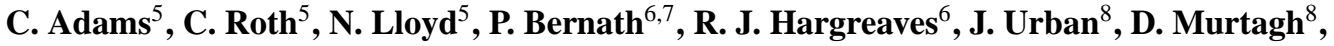 \\ A. Hauchecorne ${ }^{9}$, F. Dalaudier ${ }^{9}$, M. van Roozendael ${ }^{10}$, N. Kalb ${ }^{10}$, and C. Zehner ${ }^{11}$ \\ ${ }^{1}$ Finnish Meteorological Institute, Helsinki, Finland \\ ${ }^{2}$ Institute of Environmental Physics, University of Bremen, Bremen, Germany \\ ${ }^{3}$ Institute of Physics, University of Greifswald, Greifswald, Germany \\ ${ }^{4}$ Karlsruhe Institute of Technology, Institute for Meteorology and Climate Research, Germany \\ ${ }^{5}$ Institute for Space and Atmospheric Studies, University of Saskatchewan, Saskatoon, Saskatchewan, Canada \\ ${ }^{6}$ Department of Chemistry, University of York, York, UK \\ ${ }^{7}$ Department of Chemistry \& Biochemistry, Old Dominion University, Norfolk, VA, USA \\ ${ }^{8}$ Chalmers University of Technology, Department of Earth and Space Sciences, 41296 Gothenburg, Sweden \\ ${ }^{9}$ Université Versailles St-Quentin, UPMC University Paris 06, CNRS/INSU, LATMOS-IPSL, \\ 78280 Guyancourt, France \\ ${ }^{10}$ Belgian Institute for Space Aeronomy (IASB-BIRA), Brussels, Belgium \\ ${ }^{11}$ ESA/ESRIN, Frascati, Italy \\ Correspondence to: V. F. Sofieva (viktoria.sofieva@fmi.fi)
}

\begin{abstract}
Received: 30 May 2013 - Published in Earth Syst. Sci. Data Discuss.: 14 June 2013
Revised: 3 October 2013 - Accepted: 9 November 2013 - Published: 2 December 2013
\end{abstract}

Abstract. In this paper, we present a HARMonized dataset of OZone profiles (HARMOZ) based on limb and occultation measurements from Envisat (GOMOS, MIPAS and SCIAMACHY), Odin (OSIRIS, SMR) and SCISAT (ACE-FTS) satellite instruments. These measurements provide high-vertical-resolution ozone profiles covering the altitude range from the upper troposphere up to the mesosphere in years 2001-2012. HARMOZ has been created in the framework of the European Space Agency Climate Change Initiative project.

The harmonized dataset consists of original retrieved ozone profiles from each instrument, which are screened for invalid data by the instrument teams. While the original ozone profiles are presented in different units and on different vertical grids, the harmonized dataset is given on a common pressure grid in netCDF (network common data form)- 4 format. The pressure grid corresponds to vertical sampling of $\sim 1 \mathrm{~km}$ below $20 \mathrm{~km}$ and $2-3 \mathrm{~km}$ above $20 \mathrm{~km}$. The vertical range of the ozone profiles is specific for each instrument, thus all information contained in the original data is preserved. Provided altitude and temperature profiles allow the representation of ozone profiles in number density or mixing ratio on a pressure or altitude vertical grid. Geolocation, uncertainty estimates and vertical resolution are provided for each profile. For each instrument, optional parameters, which are related to the data quality, are also included.

For convenience of users, tables of biases between each pair of instruments for each month, as well as bias uncertainties, are provided. These tables characterize the data consistency and can be used in various bias and drift analyses, which are needed, for instance, for combining several datasets to obtain a long-term climate dataset.

This user-friendly dataset can be interesting and useful for various analyses and applications, such as data merging, data validation, assimilation and scientific research.

The dataset is available at http://www.esa-ozone-cci.org/?q=node/161 or at doi:10.5270/esa-ozone_ccilimb_occultation_profiles-2001_2012-v_1-201308. 


\section{Introduction}

The creation of homogenized ozone profile datasets based on limb or occultation measurements from sensors on board the European Space Agency (ESA) Envisat satellite, as well as from ESA Third Party Missions (TPM), is one of the primary objectives of the European Space Agency Climate Change Initiative project (Ozone_cci, http://www. esa-ozone-cci.org). Six instruments that provide long-term measurements are involved in this project. Three of them are on board Envisat: Global Ozone Monitoring by Occultation of Stars (GOMOS), Michelson Interferometer for Passive Atmospheric Sounding (MIPAS) and Scanning Imaging Spectrometer for Atmospheric Chartography (SCIAMACHY); two of them are on board Odin: Optical Spectrograph and InfraRed Imaging System (OSIRIS) and Sub-Millimeter Radiometer (SMR), and one is on board the SCISAT-1 satellite: Atmospheric Chemistry Experiment - Fourier Transform Spectrometer (ACE-FTS). Three of the instruments - GOMOS, SCIAMACHY and OSIRIS - retrieve ozone profiles from measurements in the UV-visible wavelength range. MIPAS and ACE-FTS use infrared wavelengths, and SMR operates at sub-millimeter wavelengths. Two of the instruments use the occultation technique: GOMOS uses stellar occultation and ACE-FTS performs solar occultations. SCIAMACHY and OSIRIS are limb-scattering instruments; MIPAS and SMR measure thermal emission spectra. More details on individual datasets are presented in Sect. 3. Overall, the datasets cover the years 2001-2012 (not all instruments cover the whole time period). The yearly data volume for the HARMOZ instruments is illustrated in Fig. 1. Between the various datasets, there are ozone measurements available for all seasons, various times of day, and good latitudinal coverage (as an example, Fig. 2 illustrates the latitudinal coverage in 2008).

The data from different sensors have different properties such as specific quality flags, and the data can have outliers due to problematic retrievals under some conditions. In some cases (like for GOMOS), ozone data quality strongly depends on a set of parameters, which makes using this dataset complicated for non-experts. As a first step towards data homogenization, we have created a HARMonized dataset of OZone profiles (HARMOZ). HARMOZ consists of independent datasets from individual instruments, which are carefully screened for outliers, interpolated to a common pressure grid and saved in the common netCDF (network common data form)-4 format. This database is used in various "higher-level" analyses performed within the Ozone_cci project (in particular, in creating Level 3 data, see the Ozone_cci web page http://www.esa-ozone-cci.org/ $? \mathrm{q}=$ node/160 for details). Convenience of using the harmonized dataset has prompted us to make this dataset available to the scientific community. This dataset contributes to the initiative on past changes in the vertical distribution of ozone $\left(\mathrm{SI}^{2} \mathrm{~N}\right.$ (SPARC - Stratospheric Processes and their

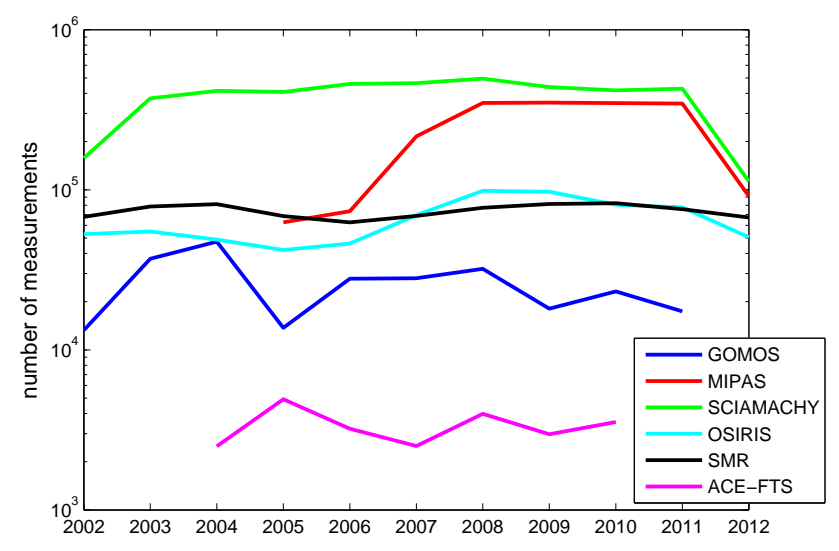

Figure 1. Number of measurements in each year and for each instrument. Number of MIPAS and SCIAMACHY measurements decrease significantly in 2012 due to the loss of Envisat. GOMOS data from year 2012 are not included in HARMOZ, because GOMOS experienced instrumental problems at that time.

Role in Climate, $\mathrm{IO}_{3} \mathrm{C}$ - International Ozone Commission, IGACO-O $_{3}$ - Integrated Global Atmospheric Chemistry Observations, NDACC - Network for the Detection of Atmospheric Composition Change) initiative, http://igaco-o3.fmi. fi/VDO/working_groups.html).

The paper is organized as follows. Section 2 presents a general description of the dataset and the data processing. Each dataset has mandatory parameters, which are the same for all instruments (discussed in Sect. 2), as well as optional, instrument-specific parameters (discussed in Sect. 3). The data format and availability are presented in Sect. 4. To characterize the data consistency, tables of biases between each pair of instruments are created. The construction and format of the bias tables are discussed in Sect. 5. The summary concludes the paper.

\section{General description of the harmonized dataset}

The individual datasets from each instrument passed quality control, which has been performed by the instrument experts. The quality control procedures are described in detail in Sect. 3. Only valid data are included in HARMOZ.

Each profile has been interpolated onto a common pressure grid (Ozone_cci pressure grid hereafter), which is an extension of the SPARC Data Initiative pressure grid (Hegglin and Tegtmeier, 2010; Tegtmeier et al., 2013). The Ozone_cci pressure levels and the corresponding pressure altitudes are presented in Appendix A. The vertical spacing of the Ozone_cci grid corresponds to $\sim 1 \mathrm{~km}$ below $20 \mathrm{~km}$ and $\sim 2-3 \mathrm{~km}$ above. The number of pressure levels included in the individual datasets depends on the valid altitude range of the ozone profiles. For example, GOMOS data are provided on the Ozone_cci grid in the range $250-10^{-4} \mathrm{hPa}$, while MIPAS data are provided in the range $400-0.05 \mathrm{hPa}$. 

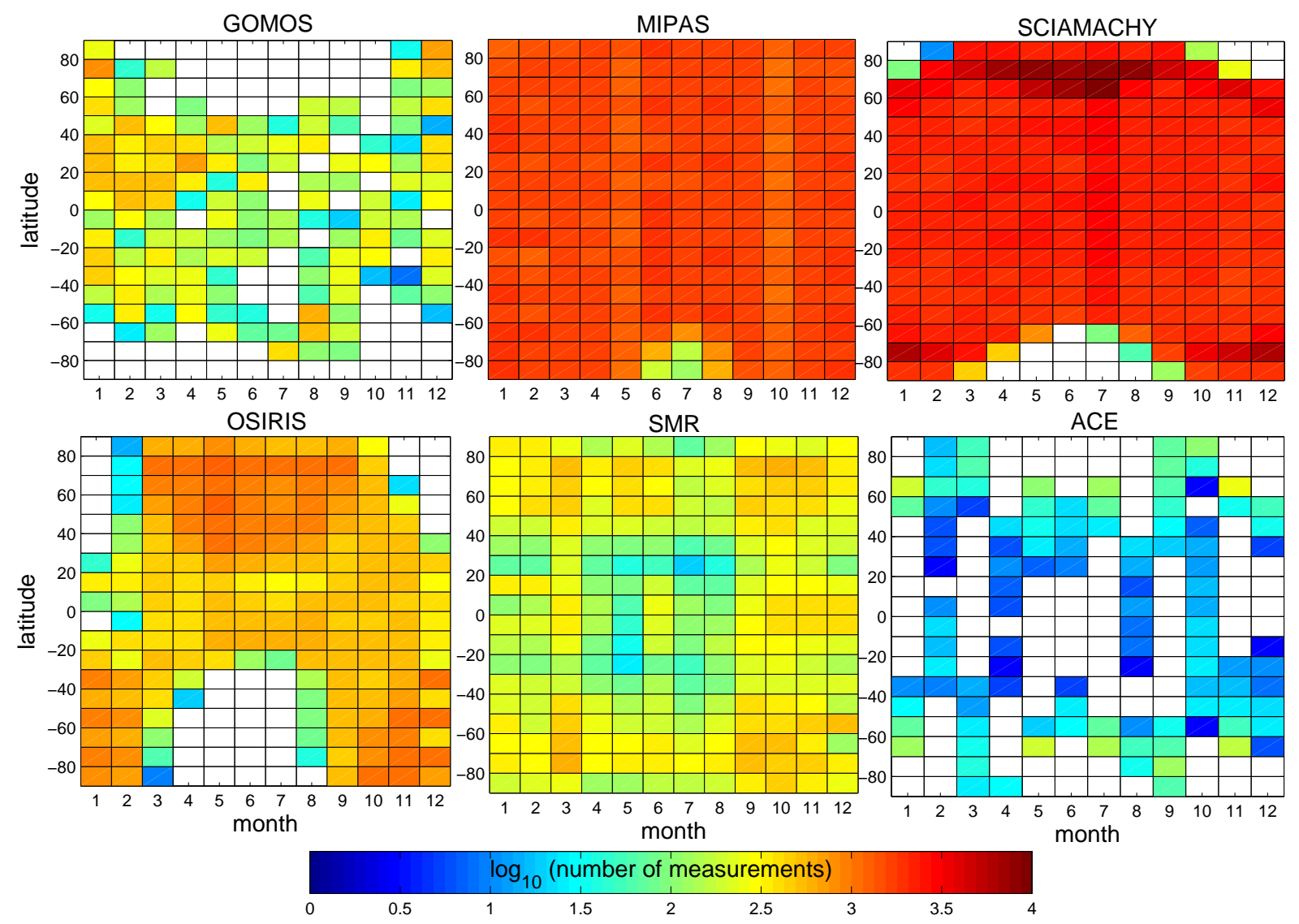

Figure 2. Logarithm of number of measurements in $10^{\circ}$ latitude zones and in each month of year 2008.

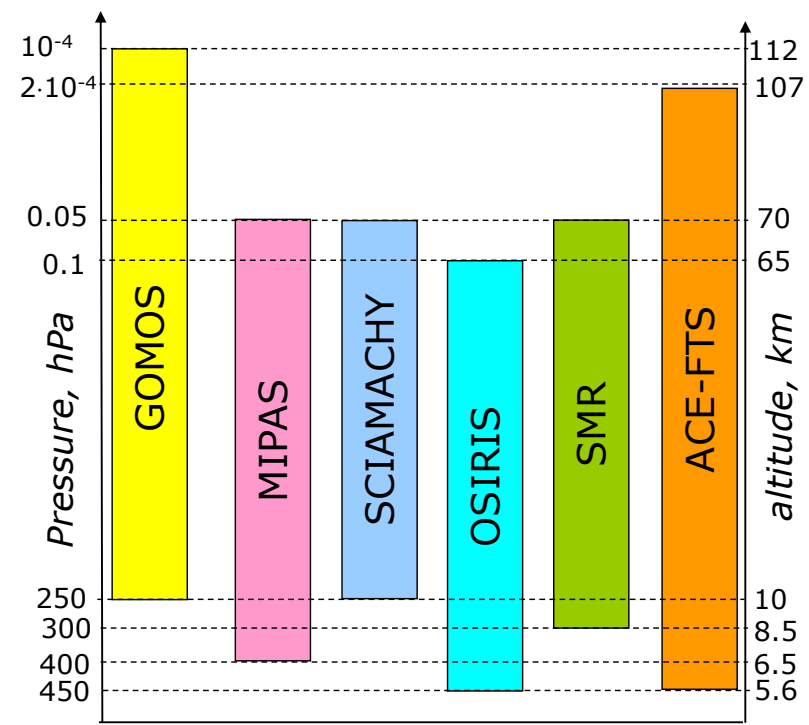

Figure 3. Illustration of altitude ranges of ozone measurements for the individual instruments in HARMOZ. The vertical axis is not to scale.
The altitude range of the individual datasets can be found in Table 1 and is illustrated in Fig. 3. The largest altitude range is achieved for occultation instruments, which cover also the lower thermosphere.

The data files contain the mandatory variables that are the same for all sensors. The main variables are profiles of ozone concentrations $\left(\right.$ moles $\mathrm{cm}^{-3}$ ) and their uncertainties. The auxiliary information includes temperature and altitude profiles at the measurement locations for converting ozone data to different units (mixing ratio/number density on pressure/altitude in all possible combinations), as well as geolocation, time, and vertical resolution. The full list of mandatory parameters is presented in Table 2 . The optional, instrument-specific parameters, which include those related to the quality of data, can be found in Table 3; they are discussed in more detail in Sect. 3. The data are written in the netCDF-4 format, in agreement with standard conventions (http://cf-pcmdi.llnl.gov/documents/cf-conventions/1. 6). Each netCDF file (for each instrument) contains the data from one month (see Sect. 5 for more details on data format).

For regridding of profiles, a linear interpolation in the logarithm-pressure vertical coordinate is used. The altitudepressure profiles needed for the interpolation are based on retrieved data or taken from the meteorological model data 
Table 1. General information about the datasets. Note that the average number of profiles per day is estimated from the average yearly volume, thus the number of profiles in each particular day can differ significantly from these average estimates.

\begin{tabular}{|c|c|c|c|c|c|c|c|}
\hline & $\begin{array}{l}\text { HARMOZ verti- } \\
\text { cal range }\end{array}$ & Local time & Vertical resolution & $\begin{array}{l}\text { Estimated } \\
\text { precision }\end{array}$ & $\begin{array}{l}\text { Average number } \\
\text { of profiles } \\
\text { per day }\end{array}$ & $\begin{array}{l}\text { Original ozone } \\
\text { unit and Level } 2 \\
\text { vertical grid }\end{array}$ & $\begin{array}{l}\text { Source of temper- } \\
\text { ature data }\end{array}$ \\
\hline GOMOS & $250-1 \times 10^{-4} \mathrm{hPa}$ & $\sim 10$ p.m. & $\begin{array}{l}2 \mathrm{~km} \text { below } 30 \mathrm{~km} \text {, } \\
3 \mathrm{~km} \text { above } 40 \mathrm{~km} \text {, } \\
\text { a linear transition } \\
\text { between }\end{array}$ & $0.5-5 \%$ & $\sim 110$ & $\begin{array}{l}\text { number density } \\
\left(\mathrm{cm}^{-3}\right) \text { on tan- } \\
\text { gent altitudes }\end{array}$ & $\begin{array}{l}\text { ECMWF } \\
\text { analysis }\end{array}$ \\
\hline MIPAS & $400-5 \times 10^{-2} \mathrm{hPa}$ & $\begin{array}{l}\sim 10 \text { p.m. and } \\
\sim 10 \text { a.m. }\end{array}$ & $\begin{array}{l}\text { profile-dependent, } \\
3-5 \mathrm{~km}\end{array}$ & $1-4 \%$ & $\sim 1000$ & $\begin{array}{l}\text { vmr on fixed al- } \\
\text { titude grid }\end{array}$ & $\begin{array}{l}\text { Retrieved } \\
\text { temperature }\end{array}$ \\
\hline SCIAMACHY & $250-5 \times 10^{-2} \mathrm{hPa}$ & $\sim 10$ a.m. & $\begin{array}{l}\text { profile-dependent, } \\
3-5 \mathrm{~km}\end{array}$ & $10-15 \%$ & $\sim 1300$ & $\begin{array}{l}\text { number density } \\
\left(\mathrm{cm}^{-3}\right) \text { on fixed } \\
\text { altitude grid }\end{array}$ & $\begin{array}{l}\text { ECMWF } \\
\text { analysis }\end{array}$ \\
\hline OSIRIS & $450-1 \times 10^{-1} \mathrm{hPa}$ & $\begin{array}{l}\sim 6 \text { a.m. and } \\
\sim 6 \text { p.m. }\end{array}$ & $\begin{array}{l}\sim 2-3 \mathrm{~km} \text {, altitude- } \\
\text { dependent }\end{array}$ & $2-10 \%$ & $\sim 250$ & $\begin{array}{l}\text { number density } \\
\left(\mathrm{cm}^{-3}\right) \text { on fixed } \\
\text { altitude grid }\end{array}$ & $\begin{array}{l}\text { ECMWF } \\
\text { analysis }\end{array}$ \\
\hline SMR & $300-5 \times 10^{-2} \mathrm{hPa}$ & $\begin{array}{l}\sim 6 \text { a.m. and } \\
\sim 6 \text { p.m. }\end{array}$ & $\begin{array}{l}\text { profile-dependent, } \\
\sim 2.5-3.5 \mathrm{~km}\end{array}$ & $\sim 20 \%$ & $\sim 250$ & $\begin{array}{l}\text { vmr on fixed } \\
\text { alt/pressure grid }\end{array}$ & $\begin{array}{l}\text { ECMWF } \\
\text { analysis }\end{array}$ \\
\hline ACE-FTS & $450-2 \times 10^{-4} \mathrm{hPa}$ & $\begin{array}{l}\text { sunrise and } \\
\text { sunset }\end{array}$ & $\sim 3 \mathrm{~km}$ & $1-3 \%$ & $\sim 11$ & $\begin{array}{l}\text { vmr on fixed al- } \\
\text { titude grid }\end{array}$ & $\begin{array}{l}\text { Retrieved }(15- \\
120 \mathrm{~km})+ \text { GEM } \\
\text { model }(0-15 \mathrm{~km})\end{array}$ \\
\hline
\end{tabular}

Table 2. Mandatory parameters in the HARMOZ netCDF files. $N_{\text {alt }}$ and $N_{\text {prof }}$ denote the number of pressure levels and the number of profiles, respectively.

\begin{tabular}{|c|c|c|}
\hline Parameter and unit & Dimensions & Description \\
\hline $\begin{array}{l}\text { time (days since } \\
\text { 1900-01-01 00:00:00) }\end{array}$ & $N_{\text {prof }} \times 1$ & The parameter to index the profiles \\
\hline air_pressure (hPa) & $N_{\text {alt }} \times 1$ & The vertical coordinate \\
\hline altitude $(\mathrm{km})$ & $N_{\text {alt }} \times N_{\text {prof }}$ & The geometric altitude above the mean sea-level \\
\hline latitude (deg north) & $N_{\text {prof }} \times 1$ & Latitude of each profile (given at altitude $\sim 35 \mathrm{~km}$ ) \\
\hline longitude (deg east) & $N_{\text {prof }} \times 1$ & Longitude of each profile (given at altitude $\sim 35 \mathrm{~km}$ ) \\
\hline $\begin{array}{l}\text { mole_concentration_of_ozone } \\
\text { _in_air }\left(\text { moles } \mathrm{cm}^{-3}\right)\end{array}$ & $N_{\text {alt }} \times N_{\text {prof }}$ & $\begin{array}{l}\text { Vertical profiles of ozone. Number density }\left(\mathrm{cm}^{-3}\right) \text { is } \\
\text { acquired by multiplying the variable with Avogadro } \\
\text { constant } N_{\mathrm{A}}=6.02214 \times 10^{23} \text { moles }^{-1}\end{array}$ \\
\hline $\begin{array}{l}\text { mole_concentration_of_ozone_in_air } \\
\text { standard_error }\left(\text { moles } \mathrm{cm}^{-3}\right)\end{array}$ & $N_{\text {alt }} \times N_{\text {prof }}$ & Uncertainty (random error) associated with the ozone profiles \\
\hline vertical_resolution $(\mathrm{km})$ & $N_{\text {alt }} \times N_{\text {prof }}$ or $N_{\text {alt }} \times 1$ & FWHM of the averaging kernel \\
\hline air_temperature $(\mathrm{K})$ & $N_{\text {alt }} \times N_{\text {prof }}$ & $\begin{array}{l}\text { Temperature profiles at the locations of measurements, for conversion } \\
\text { from concentration to mixing ratio }\end{array}$ \\
\hline
\end{tabular}

(mainly, European Centre for Medium-Range Weather Forecasts, ECMWF) at the locations of measurements (Table 1). This interpolation does not introduce significant inaccuracy, because the uncertainty of the altitude-pressure profiles is very small. For the instruments providing reliable covariance matrices of retrieval errors, the covariance matrices of uncer- tainties (random error) were interpolated as

$$
\mathbf{C}=\mathbf{W C}_{\text {orig }} \mathbf{W}^{T}
$$

where $\mathbf{C}_{\text {orig }}$ and $\mathbf{C}$ are original and interpolated matrices, respectively, and $\mathbf{W}$ is the interpolation matrix. The parameter "standard_error" contains the square roots of the diagonal elements of $\mathbf{C}$; it represents the uncertainty (random error) of 
Table 3. Optional parameters in the HARMOZ netCDF files. $N_{\text {alt }}$ and $N_{\text {prof }}$ denote the number of pressure levels and the number of profiles, respectively.

\begin{tabular}{|c|c|c|}
\hline Parameter and unit & Dimensions & Description/comment \\
\hline \multicolumn{3}{|r|}{ GOMOS } \\
\hline orbit_number & $N_{\text {prof }} \times 1$ & Envisat orbit number \\
\hline star_number & $N_{\text {prof }} \times 1$ & Star number in GOMOS catalogue \\
\hline star_magnitude & $N_{\text {prof }} \times 1$ & Star visual magnitude \\
\hline star_temperature $(\mathrm{K})$ & $N_{\text {prof }} \times 1$ & Star effective temperature \\
\hline obliquity (deg) & $N_{\text {prof }} \times 1$ & Obliquity of occultation: the angle between the orbital plane and the line of sight \\
\hline sza (deg) & $N_{\text {prof }} \times 1$ & Solar zenith angle at tangent point \\
\hline chi2 & $N_{\text {alt }} \times N_{\text {prof }}$ & $\begin{array}{l}\text { Profiles of } \chi^{2} \text {-statistics. } \chi^{2} \text { is usually close to } 1 \text {; large values indicate } \\
\text { problems with retrievals }\end{array}$ \\
\hline illumination_condition_flag & $N_{\text {prof }} \times 1$ & 0 - full dark, 3 - straylight, 2 - twilight, 4 - straylight and twilight. \\
\hline SAA_flag & $N_{\text {prof }} \times 1$ & $\begin{array}{l}\text { The indicator showing that the data might be affected by the South Atlantic } \\
\text { Anomaly (cosmic rays); } 0-\text { no, } 1-\text { yes }\end{array}$ \\
\hline \multicolumn{3}{|r|}{ SCIAMACHY } \\
\hline orbit_number & $N_{\text {prof }} \times 1$ & Envisat orbit number \\
\hline state_id & $N_{\text {prof }} \times 1$ & State ID of the SCIA measurement \\
\hline height_sat (km) & $N_{\text {prof }} \times 1$ & Satellite altitude above the sea level, for each profile \\
\hline radius_earth $(\mathrm{km})$ & $N_{\text {prof }} \times 1$ & The Earth radius at locations above the tangent points \\
\hline sza_tanpnt (deg) & $N_{\text {prof }} \times 1$ & Solar zenith angle at tangent point \\
\hline pixel_lat (deg north) & $N_{\text {prof }} \times 4$ & The ground latitudes of the four corners of the limb scan pixel \\
\hline pixel_lon (deg) & $N_{\text {prof }} \times 4$ & The ground longitude of the four corners of the limb scan pixel \\
\hline total_ozone_column (mm) & $N_{\text {prof }} \times 1$ & Total ozone column estimated for each profile; $1 \mathrm{~mm}=100 \mathrm{DU}$ (Dobson unit) \\
\hline systematic_error $(\%)$ & $N_{\text {alt }} \times N_{\text {prof }}$ & Systematic errors derived from parameter deviation simulation \\
\hline \multicolumn{3}{|r|}{ MIPAS } \\
\hline apriori_temperature $(\mathrm{K})$ & $N_{\text {alt }} \times N_{\text {prof }}$ & temperature profiles at locations of measurements based on ECMWF and MSIS data \\
\hline geo_id & $N_{\text {prof }} \times 22$ & 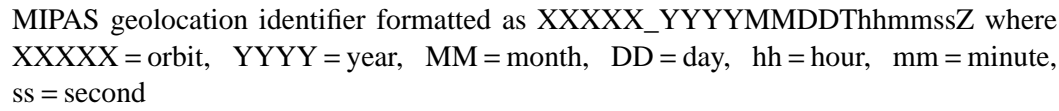 \\
\hline orbit_number & $N_{\text {prof }} \times 1$ & Envisat orbit number \\
\hline sza $(\operatorname{deg})$ & $N_{\text {prof }} \times 1$ & Solar zenith angle \\
\hline $\operatorname{chi} 2$ & $N_{\text {prof }} \times 1$ & $\chi^{2}$ value of retrievals \\
\hline & $N_{\text {prof }} \times 1$ & Degrees of freedom of target retrieval \\
\hline $\mathrm{rms}\left(\mathrm{nW} \mathrm{cm} \mathrm{cr}^{-1} \mathrm{sr}^{-1}\right)$ & $N_{\text {prof }} \times 1$ & Root mean square of residual spectra \\
\hline \multicolumn{3}{|r|}{ OSIRIS } \\
\hline scan_number & $N_{\text {prof }} \times 1$ & OSIRIS scan number \\
\hline albedo & $N_{\text {prof }} \times 1$ & Retrieved albedo \\
\hline ssa $($ deg $)$ & $N_{\text {prof }} \times 1$ & Solar scattering angle \\
\hline sza $(\operatorname{deg})$ & $N_{\text {prof }} \times 1$ & Solar zenith angle \\
\hline optics_temperature $(\mathrm{K})$ & $N_{\text {prof }} \times 1$ & Average optics box temperature \\
\hline \multicolumn{3}{|r|}{ SMR } \\
\hline quality & $N_{\text {prof }} \times 1$ & Quality flag 0: best quality, 4: tolerable \\
\hline solar_zenith_angle (deg) & $N_{\text {prof }} \times 1$ & \\
\hline local_solar_time (h) & $N_{\text {prof }} \times 1$ & \\
\hline measurement_response & $N_{\text {alt }} \times N_{\text {prof }}$ & $\begin{array}{l}\text { Proportion of measurement; measurements with weak influence of a priori have } \\
\text { measurement response close to } 1 .\end{array}$ \\
\hline $\begin{array}{l}\text { scaled_potential_ } \\
\text { vorticity }\left(\mathrm{K} \mathrm{m}^{2} \mathrm{~kg}^{-1} \mathrm{~s}^{-1}\right)\end{array}$ & $N_{\text {alt }} \times N_{\text {prof }}$ & Profiles of potential vorticity (Lait, 1994) scaled at $475 \mathrm{~K}$ potential temperature level \\
\hline equivalent_latitude (deg) & $N_{\text {alt }} \times N_{\text {prof }}$ & Profiles of equivalent latitude at locations of measurements \\
\hline \multicolumn{3}{|r|}{ ACE-FTS } \\
\hline beta_angle (deg) & $N_{\text {prof }} \times 1$ & $\begin{array}{l}\beta \text { angle is defined as the angle between the orbit plane of ACE-FTS and the vector from } \\
\text { the Sun. It is a proxy for vertical resolution. }\end{array}$ \\
\hline
\end{tabular}


Table 4. The approximate reduction factors for uncertainty estimates due to regridding (the reported values of uncertainties should be multiplied with the factor from the table).

\begin{tabular}{cccccc}
\hline GOMOS & MIPAS & SCIAMACHY & OSIRIS & SMR & ACE-FTS \\
\hline 1 & 1 & 0.94 & 0.9 & 0.85 & 0.92 \\
\hline
\end{tabular}

individual profiles. Due to the structure of $\mathbf{C}_{\text {orig }}$ and $\mathbf{W}$, diagonal elements of $\mathbf{C}$ are very slightly reduced compared to the diagonal elements of $\mathbf{C}_{\text {orig }}$. For the instruments, for which covariance matrices are not easily available or insufficiently reliable, the uncertainty estimates were simply linearly interpolated to the Ozone_cci grid (in the same way as the ozone profiles). In these cases, the reduction of uncertainties due to interpolation has been estimated based on a sample covariance matrix and the information about the vertical resolution and the original grid. This reduction is very small, of a factor $\sim 0.85-0.95$ (Table 4 ). It should be stressed here that the correction factors presented in Table 4 approximate only changes in uncertainty estimates due to regridding.

Note also that the Ozone_cci grid is finer than the vertical resolution of the ozone profiles, therefore the uncertainties at adjacent layers are correlated. Without covariances provided, there is the risk to overestimate the independent information contained in the profiles. For some of the instruments, there exist "advanced" versions of HARMOZ files with full covariance matrices $\mathbf{C}$ stored. These data can be provided upon request.

Three instruments (GOMOS, SCIAMACHY and OSIRIS) provide ozone number density profiles, thus the conversion to concentration (moles $\mathrm{cm}^{-3}$ ), the unit used in HAR$\mathrm{MOZ}$, is simply division by the Avogadro constant $N_{\mathrm{A}}=$ $6.02214 \times 10^{23} \mathrm{moles}^{-1}$. MIPAS, ACE-FTS and SMR retrieve ozone mixing ratio profiles. For MIPAS and ACEFTS, the retrieved temperature and pressure profiles were used for conversion to HARMOZ ozone concentration representation, thus making it fully consistent with the original mixing-ratio profiles. For SMR, temperature profiles are taken from the ECMWF fields. Therefore, small $(\sim 0.1 \%)$ drifts and jumps in the ECMWF density (which can be caused, for example, by different amounts of assimilated data over time, http://www.ecmwf.int/research/era/do/get/index/ QualityIssues) can induce an additional uncertainty of the same magnitude in SMR ozone concentrations reported in HARMOZ.

\section{Short descriptions of individual datasets}

In this section, a brief overview of the individual datasets is presented. The general parameters of the individual datasets are collected in Table 1 . They include information about the altitude range of individual datasets, typical local time, vertical resolution, original representation of ozone profiles, as well as the source of air density data, which can be used for conversion from ozone concentration to mixing ratio. Specific features of individual datasets are described below.

\subsection{GOMOS}

GOMOS is a stellar occultation instrument on board Envisat (Bertaux et al., 2010; Kyrölä et al., 2010). Ozone profiles are retrieved from UV-visible spectrometer measurements at wavelengths $250-692 \mathrm{~nm}$. In this dataset, nighttime ozone profiles (solar zenith angle larger than $105^{\circ}$ ) processed with the IPF version 6 processor are used. GOMOS provides stratospheric ozone profiles with vertical resolution of $2-$ $3 \mathrm{~km}$ and estimated precision of $0.5-5 \%$ (Tamminen et al., 2010). GOMOS data were filtered for outliers and unreliable data using the recommendations of the readme document http://earth.eo.esa.int/pcs/envisat/gomos/documentation/ RMF_0117_GOM_NL_2P_Disclaimers.pdf. In addition, we have excluded occultations terminated above $40 \mathrm{~km}$.

The stellar flux recorded by GOMOS, and thus signal-tonoise ratio and precision of retrieved profiles, depends on stellar magnitude and spectral class. The GOMOS optional parameters include the star identification number in the GOMOS catalogue (the smaller the star number, the brighter the star), as well as the information about the star's visual magnitude and effective temperature. Note that occultations of stars with insufficient UV flux (dim and cool stars), which cannot provide information about ozone in the upper stratosphere, are not included in the harmonized dataset. In the previous GOMOS processor, IPF version 5, ozone retrievals from dim and cool stars were problematic also in the stratosphere due to inaccurate dark charge correction and low signal-to-noise ratio (e.g., Keckhut et al., 2010). The quality of ozone profiles in such occultations in the version 6, which uses a more advanced dark charge correction method, is still under evaluation. Therefore, these data are not included in HARMOZ.

The obliquity is defined as the angle between the local vertical and the trajectory of the tangent point within the atmosphere (Gurvich and Brekhovskikh, 2001); it is $0^{\circ}$ for in-orbital-plane occultations. The vertical sampling is denser in oblique occultations. Thanks to the Tikhonov-type targetresolution regularization (Kyrölä et al., 2010; Sofieva et al., 2004) and accurate parameterization of modeling errors in the GOMOS v6 algorithm (Sofieva et al., 2009, 2010), the quality of GOMOS ozone profiles and uncertainty estimates practically does not depend on this parameter. Very oblique occultations (with obliquity larger than $85^{\circ}$ ) are not present in the harmonized dataset.

The profiles of the normalized $\chi^{2}$ statistics indicate the quality of retrievals and the quality of error estimates (normalization is on the number of spectral channels minus the number of fitted parameters, for exact definition of this parameter see e.g., Sofieva et al., 2010). Usually, $\chi_{\text {norm }}^{2}$ is very close to 1 , thus indicating the proper characterization of uncertainties. However, there are occultations in the GOMOS 
dataset that have very large $\chi_{\text {norm }}^{2}$ values. They usually correspond to the locations over the South Atlantic Anomaly (SAA), which are affected by energetic particles. From the harmonized dataset, such data are also excluded. The SAA flag presented in the list of optional parameters has been computed based on the position of the satellite. Therefore, it does not reflect the real quality of the ozone data; it is presented for information only.

The illumination flag indicates the illumination conditions (full dark limb, straylight, twilight). The bright-limb occultations (with illumination $=1$ ) are not present in the harmonized dataset. The best quality of ozone profiles and their uncertainty estimates is achieved in full dark illumination conditions. The summary of the GOMOS optional parameters is collected in Table 3.

For interpolation to the HARMOZ pressure grid, we used the ECMWF altitude-pressure profiles at occultation locations.

\subsection{MIPAS}

MIPAS is a Fourier transform spectrometer on board Envisat for the detection of limb emission spectra in the middle and upper atmosphere, which operates in the 4.15-14.6 $\mu \mathrm{m}$ wavelength range. It measures during day and night, pole-to-pole, at an altitude range from 6 to $70 \mathrm{~km}(170 \mathrm{~km})$, depending on the measurement mode, producing more than 1000 profiles per day. MIPAS provides stratospheric ozone profiles with vertical resolution of $3-5 \mathrm{~km}$ and estimated precision of $1-4 \%$.

MIPAS was working in its originally specified mode with spectral resolution of $0.035 \mathrm{~cm}^{-1}$ (unapodized) and tangent altitude steps of $3 \mathrm{~km}$ (coarser in the upper stratosphere and above) until March 2004, when an instrument failure caused a disruption of operation. The operation was resumed on 10 January 2005 with a slightly adapted observation mode: the spectral resolution had to be reduced to $0.0625 \mathrm{~cm}^{-1}$ (unapodized) since then, while the spatial sampling could be improved to $1.5-2 \mathrm{~km}$ tangent altitude step width in the stratosphere, and an along-track sampling of $410 \mathrm{~km}(550 \mathrm{~km}$ before). The finer vertical sampling allowed for better vertical resolution of the MIPAS products. However, this has the shortcoming of a not fully consistent data record before and after the change of observation mode. Currently, only data from the second period since 2005 are included in the harmonized dataset.

There exist four MIPAS Level 2 processors: the operational ESA processor and three independent research processors hosted by ISAC-CNR/University of Bologna, Oxford University and KIT IMK/IAA, respectively. All four processors use the same Level $1 \mathrm{~b}$ data, but the Level 2 algorithms are different. In the framework of Ozone_cci project, ozone profiles retrieved by the four MIPAS processors were compared. For creating the harmonized dataset, the MIPAS data were taken from the best performing pro- cessor under this comparison, which is the KIT IMK/IAA version V5R_O3_220/221 research processor (in particular, this processor has shown the best performance in the upper troposphere and lower stratosphere in comparisons with ozonesondes and lidars). The results of the processor intercomparison are described in detail in Laeng et al. (2013). The description of the KIT IMK/IAA processor can be found in von Clarmann et al. $(2003,2009)$. The dataset has been extensively validated (Laeng et al., 2012, 2013).

The following filtering was applied to the retrieved data in order to ensure the good quality of the profiles.

- The data for which the diagonal value of the averaging kernel is less (in absolute value) than 0.03 are considered unreliable and are discarded, because this corresponds to a local altitude resolution exceeding approximately the entire altitude coverage of the profile. This filter shall guarantee that only data are used which contain at least a minimum of measurement information.

- Data in parts of the atmosphere that lie below the lowermost useful tangent altitude are discarded, as they do not contain measurement information. This applies in particular to cases when the spectra measured at low tangent altitudes are discarded due to cloud contamination.

For interpolation to the HARMOZ pressure grid and for conversion to ozone concentration units, MIPAS retrieved temperature and pressure profiles have been used. The ECMWF temperature profiles at measurement locations are included as optional parameters. Several other parameters characterize the retrieval quality (Table 3 ).

\subsection{SCIAMACHY}

SCIAMACHY on board Envisat has three observation modes: nadir, limb and occultation (Bovensmann et al., 1999, 2004). The SCIAMACHY field of view is $2.6 \mathrm{~km}$ at a distance of $3000 \mathrm{~km}$ in the flight direction. The atmosphere is sampled vertically in $3.3 \mathrm{~km}$ steps in the limb mode. SCIAMACHY measures the scattered, reflected and transmitted solar radiation and covers the wavelength range between 212 and $2386 \mathrm{~nm}$ divided into 8 channels. The SCIAMACHYIUP limb retrieval algorithm (V2.9) used in this study exploits the scattered radiances in the UV and visible ranges (channel 1 at 212-334 $\mathrm{nm}$ and channels 3 and 4 covering $392-790 \mathrm{~nm}$ ) to retrieve ozone number density profiles.

While the precursor version of the SCIAMACHY-IUP limb processor (V2.3) averaged all data during the horizontal scan with a swath of $960 \mathrm{~km}$ providing one profile per limb scan, version V2.9 retrieves four profiles per scan. This results in an increased cross track horizontal resolution of $240 \mathrm{~km}$. The retrieval algorithm employs the SCIATRAN radiation transfer model (RTM) (Rozanov et al., 2001, 2013) and an inversion scheme with a first-order Tikhonov regularization. To retrieve ozone profiles, the normalized radiances 
in the UV and triplet method in the visible wavelength ranges have been used (Mieruch et al., 2012; Rahpoe et al., 2013; von Savigny et al., 2005b; Sonkaew et al., 2009). The ozone number density is retrieved in the altitude range from 8 to $70 \mathrm{~km}$.

As discussed by von Savigny et al. (2005a), pointing uncertainty is a major error source for SCIAMACHY. The pointing accuracy for the entire limb scan is estimated to be about $200 \mathrm{~m}$ (Bramstedt et al., 2012), while the relative pointing error between different tangent heights is negligibly small.

An alternative retrieval of ozone profiles from SCIAMACHY limb observations is provided by the European Space Agency/DLR (Doicu et al., 2007). The original retrieval was based upon retrievals from visible wavelengths only covering the Chappuis ozone absorption bands. This limits the retrieved altitudes to below $40 \mathrm{~km}$ compared to about $65 \mathrm{~km}$ in the SCIAMACHY-IUP retrieval.

SCIAMACHY provides stratospheric ozone profiles with vertical resolution of 3-5 $\mathrm{km}$ and estimated precision of 10 $15 \%$ (Rahpoe et al., 2013). Ozone data are usually of poor quality in cloudy conditions. Therefore, data at altitudes contaminated by clouds are filtered out in the harmonized dataset. For interpolation to the HARMOZ pressure grid, we used the ECMWF altitude-pressure profiles at measurement locations.

\subsection{OSIRIS}

OSIRIS on board the Odin satellite has been taking limbscattered measurements of the atmosphere from 2001 to present. It operates at wavelengths of $280-810 \mathrm{~nm}$. For the harmonized dataset, the OSIRIS SaskMART v5.0x ozone data (Degenstein et al., 2009; Roth et al., 2007), which is retrieved using the SASKTRAN spherical radiative transfer model (Bourassa et al., 2008), have been used. The data have been filtered for outliers according to the techniques described by Adams et al. (2013a). This involves a threestep process: (1) radiances are screened for evidence of clouds and energetic particles; (2) retrieved ozone profiles are screened using statistical techniques; and (3) retrieved ozone profiles are assessed visually (for details, see Appendix A in Adams et al., 2013a). OSIRIS provides stratospheric ozone profiles with vertical resolution of $2-3 \mathrm{~km}$ and estimated precision of 2-10\% (Bourassa et al., 2012).

During inter-comparisons with other satellite and in situ measurements (Adams et al., 2013a, b), it was found that agreement between OSIRIS and the validation datasets depends on the OSIRIS optics temperature, retrieved aerosols and albedo. These are included as optional parameters in the OSIRIS harmonized dataset.

For interpolation to the HARMOZ pressure grid, we used the ECMWF altitude-pressure profiles at measurement locations.

\subsection{SMR}

SMR on board the Odin satellite has been measuring thermal emissions since 2001 to present. For SMR, the version 2.1, $501.8 \mathrm{GHz}$ band retrievals are presently (April 2013) recommended for use. SMR measures ozone also independently in other bands and results from these bands will be included at a later stage. The Level 2 products from the $501.8 \mathrm{GHz}$ band provide ozone data in the $\sim 12-60 \mathrm{~km}$ altitude range (above $17-18 \mathrm{~km}$ at midlatitudes) with $2.5-3.5 \mathrm{~km}$ vertical resolution and a single-profile precision of about $20 \%$. The systematic error is estimated to be smaller than $0.75 \mathrm{ppmv}$ (e.g., Urban et al., 2005, 2006). Note that measurements in this observation mode were carried out every third day until April 2007 and every other day thereafter. The thermal emission technique allows ozone to be measured during day and night. Global fields between $\sim 83^{\circ} \mathrm{S}$ and $\sim 83^{\circ} \mathrm{N}$ are typically produced from $14-15$ orbits per observation day based on up to $65 \mathrm{limb}$ scans per orbit. Since they are derived from a relatively weak spectral line, individual ozone profiles are quite noisy but averages agree reasonably well with correlative measurements (e.g., Dupuy et al., 2009; Jégou et al., 2008; Jones et al., 2007).

For HARMOZ, SMR data with a quality flag equal to 0 or 4 and a measurement response larger than 0.67 have been used. A filtering of outliers (also using data from other simultaneously retrieved species such as $\mathrm{N}_{2} \mathrm{O}$ and $\mathrm{ClO}$ ) has also been applied. For SMR, vertical resolution is estimated from the full-width-at-half-maximum (FWHM) of averaging kernel functions calculated (offline by the retrieval algorithm) for 4 observation days in 2010 (mid-March, midJune, mid-September, mid-December). The FWHM profiles were interpolated on the HARMOZ pressure grid and zonal means were calculated in $10^{\circ}$ wide latitude zones. The derived FWHM climatology indicates thus typical values of the altitude resolution as a function of latitude and pressure.

The most important optional parameter is the measurement response, which indicates the fraction of measurement information in the retrieved profiles. In the case of a very weak influence of the a priori, the measurement response is close to 1 . In our studies within the Ozone_cci project, we use the data with the measurement response larger than 0.75 . Users may use a higher threshold value and apply stricter filtering depending on application.

For the SMR $501.8 \mathrm{GHz}$ band, retrievals use ECMWF temperature and pressure profiles at the measurement locations. Consistently, the same temperature/pressure profiles have been used for interpolation to the HARMOZ grid and for conversion of retrieved volume mixing ratios to ozone concentrations.

\subsection{ACE-FTS}

ACE-FTS is a solar occultation instrument that records spectra between 2.2 and $13.3 \mu \mathrm{m}\left(750-4400 \mathrm{~cm}^{-1}\right)$ at a high 
spectral resolution of $0.02 \mathrm{~cm}^{-1}$ (Bernath et al., 2005). ACEFTS provides retrieved altitude profiles of the volume mixing ratio (vmr) of ozone on a $1 \mathrm{~km}$ native grid. Each measurement is made at the time of local sunrise/sunset. ACE-FTS provides stratospheric ozone profiles with vertical resolution of $\sim 3 \mathrm{~km}$ and estimated precision of $1-3 \%$.

For HARMOZ, the version 3.0 processed data from March 2004 to September 2010 have been used. These data have been filtered to only include data points that are within 5 median absolute deviations (MADs) from the vmr median. Additionally, any data point for which the vmr error exceeds the measurement has also been excluded.

The temperature profiles, which are included in the netCDF files, are determined in two parts. Between 0 and $15 \mathrm{~km}$, values from the GEM operational weather model of Environment Canada are used. Between 15 and $125 \mathrm{~km}, \mathrm{CO}_{2}$ lines are used for direct temperature retrievals (Boone et al., 2005). The corresponding pressure profiles were used for interpolation of ozone profiles from altitude to the pressure (HARMOZ) grid and for conversion of retrieved volume mixing ratios to ozone concentrations.

For this study, it is useful to include the beta angle (angle between orbital plane and the Sun-Earth vector) as an optional parameter for each profile, as this can give an indication of the vertical spacing. ACE initially takes measurements on a tangent-altitude grid and the vertical spacing of this grid varies depending on the beta angle. When the beta angle is at a minimum $\left(0^{\circ}\right)$, the vertical spacing can be as high as $6 \mathrm{~km}$ at high altitude, which means that the occultation is almost perpendicular to Earth's surface. However, when the beta angle is at a maximum (set to about $65^{\circ}$ ) the vertical spacing can be as low as $2 \mathrm{~km}$ (at high altitudes) because now ACE measurements are at an oblique angle to Earth's surface. It is not a straightforward problem to determine the vertical resolution of each occultation because this is dependent on a number of factors including the beta angle. It is best to estimate the vertical resolution as an average of $3 \mathrm{~km}$ for all points and the beta angle is provided to indicate the quality of this estimate. A vertical resolution of $3 \mathrm{~km}$ is typically used when validating ACE-FTS measurements (Dupuy et al., 2009).

\section{Data format and availability}

The harmonized dataset is provided in netCDF-4 format (with README file) and can be found at the Ozone_cci web page http://www.esa-ozone-cci.org/?q=node/161 (or doi:10.5270/esa-ozone_cci-limb_occultation_profiles2001_2012-v_1-201308). It consists of folders corresponding to satellite and instrument. Each folder contains monthly data files with self-explanatory names. For example, the file ESACCI-OZONE-L2-LP-GOMOS_ENVISAT-IPF_V6200801_fv0004.nc contains GOMOS ozone profiles for January 2008. The parameters in the files are compliant with
CF-1.5 convention. Sample scripts to read the netCDF-4 files with MATLAB, IDL and IGOR Pro are also available on the web page.

\section{Data agreement tables}

To quantify the agreement between the individual datasets in HARMOZ, tables of experimental biases between each pair of instruments are provided, as well as the uncertainty of the bias estimates. The data agreement tables are computed using collocated measurements with the following restrictions on time difference $\Delta t$, distance between tangent points $\Delta d$, and latitude difference $\Delta \theta$ :

i. standard collocation: $|\Delta t| \leq 24 \mathrm{~h},|\Delta d| \leq 1000 \mathrm{~km},|\Delta \theta| \leq$ $2^{\circ}$.

ii. tight collocation: $|\Delta t| \leq 4 \mathrm{~h},|\Delta d| \leq 400 \mathrm{~km}$.

The tight collocation criterion is based on the effective horizontal resolution of the considered limb/occultation measurements, and can be considered therefore as the "natural" collocation criterion. The standard criterion ensures a sufficient number of collocated measurements and thus provides reliable bias estimates with better seasonal and latitudinal coverage. Analogous criteria have previously been successfully applied in satellite inter-comparisons (Adams et al., 2013a, b; Kyrölä et al., 2013). In the case of multiple collocated measurements, only the nearest in time is selected.

For all pairs of instruments, the bias tables are provided for the standard collocation criterion. When possible, the bias tables for tight collocation criterion are also provided; these are for pairs involving the dense samplers MIPAS and SCIAMACHY.

The vertical resolution is $\sim 3 \mathrm{~km}$ for all instruments (slightly smaller for GOMOS and OSIRIS, slightly larger for MIPAS and SCIAMACHY). The difference in vertical resolution between the HARMOZ instruments cannot generate significant systematic differences in ozone profiles (they can be as large as $\sim 1-2 \%$ in the worst cases, as estimated via comparison of original GOMOS data (the best vertical resolution, $2-3 \mathrm{~km}$ ) and the same data but smoothed down to $3.6-4.2 \mathrm{~km}$ vertical resolution, the approximate vertical resolution of MIPAS and SCIAMACHY). Therefore, we ignored the difference in vertical resolution in the bias analysis.

The analysis of ozone differences between Ozone_cci limb instruments has shown that biases are additive rather than multiplicative. Therefore, we calculate the relative bias $b$ as

$b=2 \frac{\left\langle x_{1}-x_{2}\right\rangle}{\left\langle x_{1}\right\rangle+\left\langle x_{2}\right\rangle}$,

where $x_{1}$ and $x_{2}$ are collocated measurements from two instruments at a given altitude and $\langle$.$\rangle denotes mean/median$ estimates (both are provided). The relative uncertainty of $b$ is estimated as

$\sigma_{b}=\frac{2}{\left\langle x_{1}\right\rangle+\left\langle x_{2}\right\rangle} \cdot \frac{\sigma_{\left(x_{1}-x_{2}\right)}}{\sqrt{N}}$, 
Table 5. Main parameters of bias tables in the netCDF format.

\begin{tabular}{|c|c|c|}
\hline Parameter and unit & Dimensions & Description/comment \\
\hline \multicolumn{3}{|r|}{ Variables } \\
\hline air_pressure $(\mathrm{hPa})$ & $N_{\text {alt }} \times 1$ & The vertical coordinate \\
\hline approximate_altitude $(\mathrm{km})$ & $N_{\text {alt }} \times 1$ & $\begin{array}{l}\text { Approximate altitude at pressure levels computed as } z=16 \log _{10}(1013 / P) \text {, } \\
P \text { is pressure in } \mathrm{hPa}\end{array}$ \\
\hline latitude_centers (deg north) & $N_{\text {lat }} \times 1$ & Centers of latitude bins: $80^{\circ} \mathrm{S}, 60^{\circ} \mathrm{S}, 40^{\circ} \mathrm{S}, 20^{\circ} \mathrm{S}, 0^{\circ}, 20^{\circ} \mathrm{N}, 40^{\circ} \mathrm{N}, 60^{\circ} \mathrm{N}, 80^{\circ} \mathrm{N}$ \\
\hline $\operatorname{bias}(\%)$ & $N_{\text {lat }} \times N_{\text {alt }}$ & $\begin{array}{l}\text { Bias between instrument } \# 1 \text { and instrument \#2 estimated as the mean of differences, } \\
\text { Eq. ( } 2 \text { ) }\end{array}$ \\
\hline robust_bias $(\%)$ & $N_{\text {lat }} \times N_{\text {alt }}$ & As "bias", but the median estimates are used \\
\hline bias_uncertainty $(\%)$ & $N_{\text {lat }} \times N_{\text {alt }}$ & Uncertainty of the bias estimated using the standard sample std of differences, Eq. (3) \\
\hline robust_bias_uncertainty (\%) & $N_{\text {lat }} \times N_{\text {alt }}$ & Uncertainty of the bias estimated using the robust sample std of differences, Eq. (3) \\
\hline number_of_collocated_data & $N_{\text {lat }} \times N_{\text {alt }}$ & number of collocated data in each latitude bin and at each pressure level \\
\hline
\end{tabular}
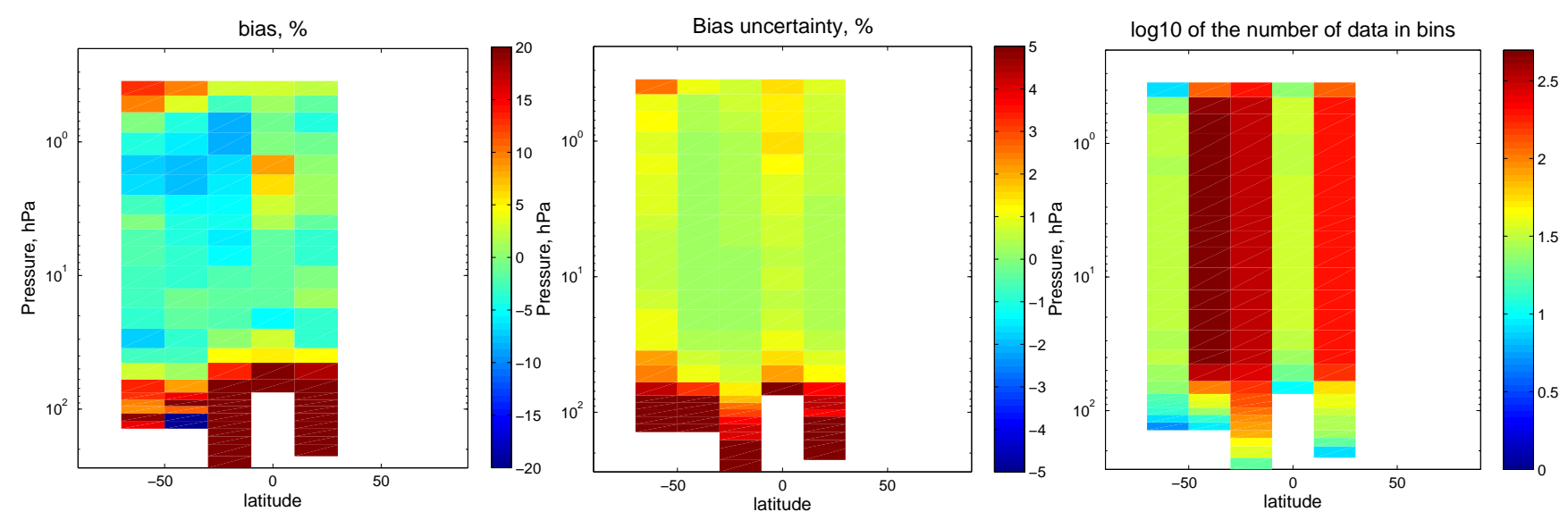

Figure 4. A visualization example of bias-related parameters from bias tables, for GOMOS versus OSIRIS in January 2008.

where $\sigma_{\left(x_{1}-x_{2}\right)}$ is the sample standard deviation of the difference distribution computed in a standard or in a robust way as $\sigma=\frac{1}{2}\left(P_{84}-P_{16}\right), P_{84}$ and $P_{16}$ are 84 th and 16 th percentiles, respectively, and $N$ is the number of collocated measurements. In the agreement tables, both parameters $b$ and $\sigma_{b}$ are expressed as percentages. The estimates using the median and percentiles are referred to as "robust" in the created files. Equation (3) represents the standard error of the mean derived assuming uncorrelated randomly sampled measurement pairs. This assumption is appropriate for nearly all HARMOZ pairs due to the properties of data and the method for selecting the collocated measurement. For MIPAS-SCIAMACHY collocations, deviations from assumption are possible; this problem is discussed in Toohey and von Clarmann (2013). The bias is evaluated over the common altitude range of the pair of instruments, using concentration profiles. The bias is evaluated for each month in $20^{\circ}$ latitude zones from $90^{\circ} \mathrm{S}$ to $90^{\circ} \mathrm{N}$. The bias tables are structured in 15 folders corresponding to the instrument pairs, e.g., "GOMOS_OSIRIS". They can be found at the same web page http://www.esa-ozone-cci.org/?q=node/161 (or doi:10.5270/esa-ozone_cci-limb_occultation_profiles- 2001_2012-v_1-201308). The folders contain bias tables corresponding to each month in netCDF-4 format. The file names contain information about the year and the month, as well as the instruments and the collocation type. For example, the file ESACCI-OZONEAgreementTable_GOMOS_OSIRIS_200801.nc contains the bias table between GOMOS $\left(x_{1}\right)$ and OSIRIS $\left(x_{2}\right)$ for January 2008, for the standard collocation criterion. The files for tight collocation criterion end with "_tight.nc". The parameters included in the netCDF files are presented in Table 5. A sample visual representation of the main bias parameters is shown in Fig. 4.

The data agreement tables present experimental estimates of biases and their uncertainties. At some locations and seasons, the estimated biases can be not statistically significant. Furthermore, discrepancies at upper altitudes are expected (and observed), because of diurnal ozone variations (e.g., Sakazaki et al., 2013, and references therein). The created bias tables are convenient for higher-level analyses, which might aim at detecting statistically significant biases, their latitudinal dependence, and possible drift in time. Examples of such higher-level analyses are presented in Figs. 5 and 6. A 

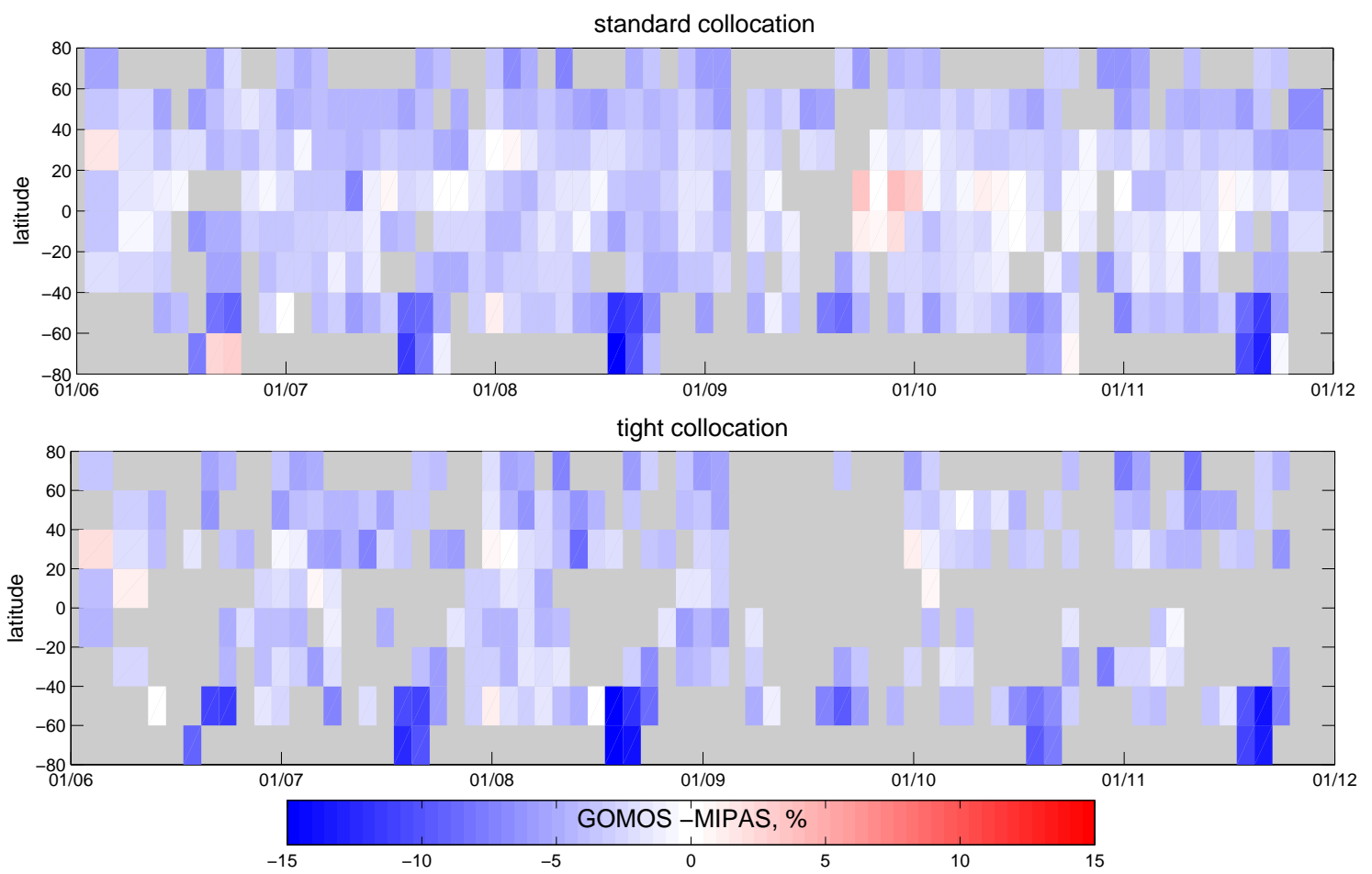

Figure 5. GOMOS minus MIPAS (in \% indicated by color scale) at $30 \mathrm{~km}$, as a function of latitude and time, for standard (top) and tight (bottom) collocation criteria.

detailed analysis of biases and drifts between the instruments will be presented in a separate paper.

Figure 5 shows the time-latitude dependence of biases for "GOMOS minus MIPAS" at $15 \mathrm{hPa}(\sim 30 \mathrm{~km})$, for standard and tight collocation criteria. As seen in Fig. 5, the wider collocation criteria do not significantly change the observed biases. At the majority of locations, GOMOS reports slightly smaller ozone values, and this difference is stable in time.

Figure 6 shows mean (over all seasons) biases for 20072008 with respect to MIPAS, as a function of latitude and altitude (subplots show relative differences for "instrument minus MIPAS"). The weighted mean (with uncertainties of individual biases) is used for averaging of monthly bias values. Since the number of collocations with MIPAS over the considered two years is large, the observed differences are statistically significant. Two features can be easily noticed in Fig. 6. First, MIPAS is biased high at altitudes of $40-45 \mathrm{~km}$ with respect to all instruments. This feature has also been noticed in MIPAS validation studies (Laeng et al., 2012, 2013). Second, a visible enhancement in SCIAMACHY data in the equatorial atmosphere at $\sim 30 \mathrm{~km}$ is observed. This feature is unique for SCIAMACHY and also has been observed previously (Mieruch et al., 2012). The presented examples are only simple illustrations of possible analyses using the harmonized dataset and the data agreement tables.

\section{Summary}

We have described the HARMonized dataset of OZone profiles (HARMOZ) based on limb and occultation data from six satellite instruments: GOMOS, MIPAS, SCIAMACHY, OSIRIS, SMR and ACE-FTS. The main strength of HAR$\mathrm{MOZ}$ is that it is user-friendly: the independent datasets from individual instruments, which passed thorough quality control, are presented in the same form as far as possible (common vertical grid, common parameters, and a common data format). Although the datasets are simple and user-friendly, they are also comprehensive: all important parameters attributed to individual datasets are presented. Quality of ozone profiles in HARMOZ is characterized by uncertainty estimates and the vertical resolution. The created data agreement tables provide ready information for various bias and drift analyses. This information is of high importance in joint data analyses and in data merging. A detailed analysis of biases and drifts between the Ozone_cci instruments will be the subject of a future publication.

Between the various datasets, there are ozone measurements available for all seasons, various times of day, and good latitudinal coverage. This user-friendly dataset can be very interesting and useful for different analyses and applications, such as data merging, data validation, different intercomparisons, data assimilation and scientific research. The system has been designed in a flexible and open way in order 

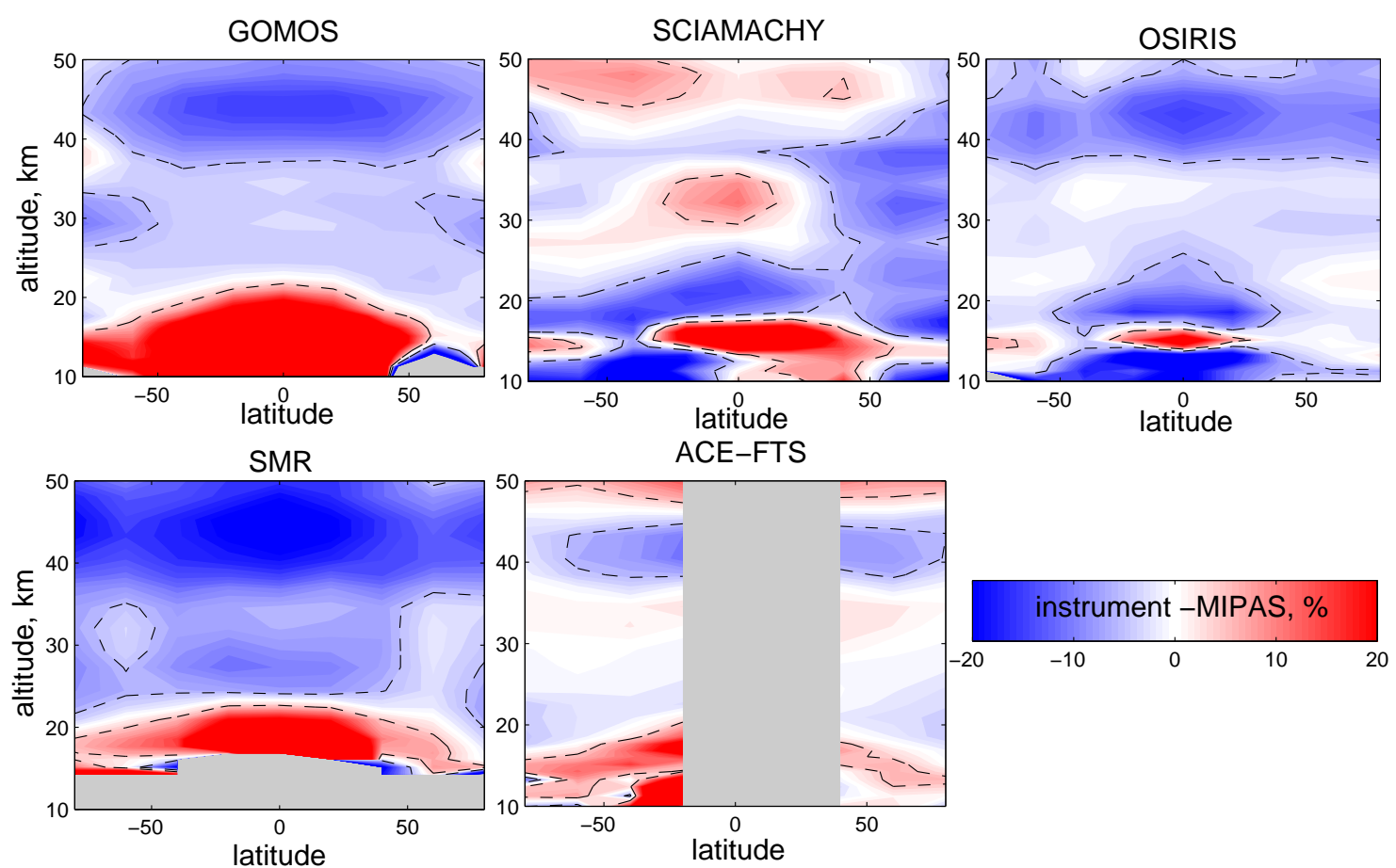

Figure 6. Latitude-altitude dependence of biases with respect to MIPAS (“instrument minus MIPAS" in \% is shown in color scale). Dashed black lines indicate $\pm 5 \%$.

to facilitate the ingestion of additional datasets from other instruments and/or from other processors, when these become available.

\section{Appendix A}

The pressure levels $(P, \mathrm{hPa})$ of the Ozone_cci grid are the following:

$450,400,350,300,250,200,170,150,130,115,100$, $90,80,70,50,40,30,20,15,10,7,5,4,3,2,1,1.5$, $1,0.7,0.5,0.4,0.3,0.2,0.15,0.1,0.07,0.05,0.04,0.03$, $0.02,0.015,0.01,0.007,0.005,0.004,0.003,0.002,0.0015$, $0.001,0.0007,0.0005,0.0004,0.0003,0.0002,0.00015$, 0.0001 .

The corresponding pressure altitudes $z=16 \log _{10}(1013 / P)$ in $\mathrm{km}$ are the following:

$5.64,6.46,7.38,8.46,9.72,11.27,12.4,13.27,14.27$, $15.12,16.09,16.82,17.64,18.57,20.91,22.46,24.46$, $27.27,29.27,32.09,34.57,36.91,38.46,40.46,43.27$, $48.09,45.27,48.09,50.57,52.91,54.46,56.46,59.27$, $61.27,64.09,66.57,68.91,70.46,72.46,75.27,77.27$, $80.09,82.57,84.91,86.46,88.46,91.27,93.27,96.09$, $98.57,100.91,102.46,104.46,107.27,109.27,112.09$.
Acknowledgements. This work has been performed in the framework of the ESA Ozone_cci project.

Edited by: D. Loyola

\section{References}

Adams, C., Bourassa, A. E., Bathgate, A. F., McLinden, C. A., Lloyd, N. D., Roth, C. Z., Llewellyn, E. J., Zawodny, J. M., Flittner, D. E., Manney, G. L., Daffer, W. H., and Degenstein, D. A.: Characterization of Odin-OSIRIS ozone profiles with the SAGE II dataset, Atmos. Meas. Tech., 6, 1447-1459, doi:10.5194/amt6-1447-2013, 2013a.

Adams, C., Bourassa, A. E., Sofieva, V., Froidevaux, L., McLinden, C. A., Hubert, D., Lambert, J. -C., Sioris, C. E., and Degenstein, D. A.: Assessment of Odin-OSIRIS ozone measurements from 2001 to the present using MLS, GOMOS, and ozone sondes, Atmos. Meas. Tech. Discuss., 6, 3819-3857, doi:10.5194/amtd-63819-2013, 2013b.

Bernath, P. F., McElroy, C. T., Abrams, M. C., Boone, C. D., Butler, M., Camy-Peyret, C., Carleer, M., Clerbaux, C., Coheur, P.-F., Colin, R., DeCola, P., DeMazière, M., Drummond, J. R., Dufour, D., Evans, W. F. J., Fast, H., Fussen, D., Gilbert, K., Jennings, D. E., Llewellyn, E. J., Lowe, R. P., Mahieu, E., McConnell, J. C., McHugh, M., McLeod, S. D., Michaud, R., Midwinter, C., Nassar, R., Nichitiu, F., Nowlan, C., Rinsland, C. P., Rochon, Y. J., Rowlands, N., Semeniuk, K., Simon, P., Skelton, R., Sloan, J. J., Soucy, M.-A., Strong, K., Tremblay, P., Turnbull, D., Walker, K. A., Walkty, I., Wardle, D. A., Wehrle, V., Zander, R., and Zou, J.: Atmospheric Chemistry Experiment (ACE): Mission overview, 
Geophys. Res. Lett., 32, L15S01, doi:10.1029/2005GL022386, 2005.

Bertaux, J. L., Kyrölä, E., Fussen, D., Hauchecorne, A., Dalaudier, F., Sofieva, V., Tamminen, J., Vanhellemont, F., Fanton d'Andon, O., Barrot, G., Mangin, A., Blanot, L., Lebrun, J. C., Pérot, K., Fehr, T., Saavedra, L., Leppelmeier, G. W., and Fraisse, R.: Global ozone monitoring by occultation of stars: an overview of GOMOS measurements on ENVISAT, Atmos. Chem. Phys., 10, 12091-12148, doi:10.5194/acp-10-12091-2010, 2010.

Boone, C. D., Nassar, R., Walker, K. A., Rochon, Y., McLeod, S. D., Rinsland, C. P., and Bernath, P. F.: Retrievals for the atmospheric chemistry experiment Fourier-transform spectrometer, Appl. Optics, 44, 7218-7231, http://ao.osa.org/abstract.cfm? URI=ao-44-33-7218, 2005.

Bourassa, A. E., Degenstein, D. A., and Llewellyn, E. J.: SASKTRAN: A spherical geometry radiative transfer code for efficient estimation of limb scattered sunlight, J. Quant. Spectrosc. Ra., 109, 52-73, doi:10.1016/j.jqsrt.2007.07.007, 2008.

Bourassa, A. E., McLinden, C. A., Bathgate, A. F., Elash, B. J., and Degenstein, D. A.: Precision estimate for OdinOSIRIS limb scatter retrievals, J. Geophys. Res., 117, D04303, doi:10.1029/2011JD016976, 2012.

Bovensmann, H., Burrows, J. P., Buchwitz, M., Frerick, J., Noël, S., Rozanov, V. V., Chance, K. V., and Goede, A. P. H.: SCIAMACHY: Mission Objectives and Measurement Modes, J. Atmos. Sci., 56, 127-150, doi:10.1175/15200469(1999)056<0127:SMOAMM>2.0.CO;2, 1999.

Bovensmann, H., Buchwitz, M., Frerick, J., Hoogeveen, R. W. M., Kleipool, Q., Lichtenberg, G., Noel, S., Richter, A., Rozanov, A., Rozanov, V. V., Skupin, J., von Savigny, C., Wuttke, M. W., and Burrows, J. P.: SCIAMACHY on ENVISAT: in-flight optical performance and first results, in: Remote Sensing of Clouds and the Atmosphere VIII, edited by: Schaefer, K., Comeron, A., Carleer, M. R., and Picard, R. H.: Proceedings of the SPIE, 5235, 160-173, 2004.

Bramstedt, K., Noël, S., Bovensmann, H., Gottwald, M., and Burrows, J. P.: Precise pointing knowledge for SCIAMACHY solar occultation measurements, Atmos. Meas. Tech., 5, 2867-2880, doi:10.5194/amt-5-2867-2012, 2012.

Degenstein, D. A., Bourassa, A. E., Roth, C. Z., and Llewellyn, E. J.: Limb scatter ozone retrieval from 10 to $60 \mathrm{~km}$ using a multiplicative algebraic reconstruction technique, Atmos. Chem. Phys., 9, 6521-6529, doi:10.5194/acp-9-6521-2009, 2009.

Doicu, A., Schreier, F., Hilgers, S., von Bargen, A., Slijkhuis, S., Hess, M., and Aberle, B.: An efficient inversion algorithm for atmospheric remote sensing with application to UV limb observations, J. Quant. Spectrosc. Ra., 103, 193-208, doi:10.1016/j.jqsrt.2006.05.007, 2007.

Dupuy, E., Walker, K. A., Kar, J., Boone, C. D., McElroy, C. T., Bernath, P. F., Drummond, J. R., Skelton, R., McLeod, S. D., Hughes, R. C., Nowlan, C. R., Dufour, D. G., Zou, J., Nichitiu, F., Strong, K., Baron, P., Bevilacqua, R. M., Blumenstock, T., Bodeker, G. E., Borsdorff, T., Bourassa, A. E., Bovensmann, H., Boyd, I. S., Bracher, A., Brogniez, C., Burrows, J. P., Catoire, V., Ceccherini, S., Chabrillat, S., Christensen, T., Coffey, M. T., Cortesi, U., Davies, J., De Clercq, C., Degenstein, D. A., De Mazière, M., Demoulin, P., Dodion, J., Firanski, B., Fischer, H., Forbes, G., Froidevaux, L., Fussen, D., Gerard, P., GodinBeekmann, S., Goutail, F., Granville, J., Griffith, D., Haley, C.
S., Hannigan, J. W., Höpfner, M., Jin, J. J., Jones, A., Jones, N. B., Jucks, K., Kagawa, A., Kasai, Y., Kerzenmacher, T. E., Kleinböhl, A., Klekociuk, A. R., Kramer, I., Küllmann, H., Kuttippurath, J., Kyrölä, E., Lambert, J.-C., Livesey, N. J., Llewellyn, E. J., Lloyd, N. D., Mahieu, E., Manney, G. L., Marshall, B. T., McConnell, J. C., McCormick, M. P., McDermid, I. S., McHugh, M., McLinden, C. A., Mellqvist, J., Mizutani, K., Murayama, Y., Murtagh, D. P., Oelhaf, H., Parrish, A., Petelina, S. V., Piccolo, C., Pommereau, J.-P., Randall, C. E., Robert, C., Roth, C., Schneider, M., Senten, C., Steck, T., Strandberg, A., Strawbridge, K. B., Sussmann, R., Swart, D. P. J., Tarasick, D. W., Taylor, J. R., Tétard, C., Thomason, L. W., Thompson, A. M., Tully, M. B., Urban, J., Vanhellemont, F., Vigouroux, C., von Clarmann, T., von der Gathen, P., von Savigny, C., Waters, J. W., Witte, J. C., Wolff, M., and Zawodny, J. M.: Validation of ozone measurements from the Atmospheric Chemistry Experiment (ACE), Atmos. Chem. Phys., 9, 287-343, doi:10.5194/acp-9-287-2009, 2009.

Gurvich, A. S. and Brekhovskikh, V.: A study of turbulence and inner waves in the stratosphere based on the observations of stellar scintillations from space: A model of scintillation spectra, Wave. Random Media, 11, 163-181, 2001.

Hegglin, M. I. and Tegtmeier, S.: The SPARC Data Initiative, SPARC Newsl. No. 36, 22, 2010.

Jégou, F., Urban, J., de La Noë, J., Ricaud, P., Le Flochmoën, E., Murtagh, D. P., Eriksson, P., Jones, A., Petelina, S., Llewellyn, E. J., Lloyd, N. D., Haley, C., Lumpe, J., Randall, C., Bevilacqua, R. M., Catoire, V., Huret, N., Berthet, G., Renard, J. B., Strong, K., Davies, J., Mc Elroy, C. T., Goutail, F., and Pommereau, J. P.: Technical Note: Validation of Odin/SMR limb observations of ozone, comparisons with OSIRIS, POAM III, ground-based and balloon-borne instruments, Atmos. Chem. Phys., 8, 3385-3409, doi:10.5194/acp-8-3385-2008, 2008.

Jones, A., Murtagh, D., Urban, J., Eriksson, P., and Rösevall, J.: Intercomparison of Odin/SMR ozone measurements with MIPAS and balloon sonde data, Can. J. Phys., 85, 1111-1123, doi:10.1139/p07-118, 2007.

Keckhut, P., Hauchecorne, A., Blanot, L., Hocke, K., GodinBeekmann, S., Bertaux, J.-L., Barrot, G., Kyrölä, E., van Gijsel, J. A. E., and Pazmino, A.: Mid-latitude ozone monitoring with the GOMOS-ENVISAT experiment version 5: the noise issue, Atmos. Chem. Phys., 10, 11839-11849, doi:10.5194/acp10-11839-2010, 2010.

Kyrölä, E., Tamminen, J., Sofieva, V., Bertaux, J. L., Hauchecorne, A., Dalaudier, F., Fussen, D., Vanhellemont, F., Fanton d'Andon, O., Barrot, G., Guirlet, M., Mangin, A., Blanot, L., Fehr, T., Saavedra de Miguel, L., and Fraisse, R.: Retrieval of atmospheric parameters from GOMOS data, Atmos. Chem. Phys., 10, 1188111903, doi:10.5194/acp-10-11881-2010, 2010.

Kyrölä, E., Laine, M., Sofieva, V., Tamminen, J., Päivärinta, S.-M., Tukiainen, S., Zawodny, J., and Thomason, L.: Combined SAGE II-GOMOS ozone profile data set for 1984-2011 and trend analysis of the vertical distribution of ozone, Atmos. Chem. Phys., 13, 10645-10658, doi:10.5194/acp-13-10645-2013, 2013.

Laeng, A., Grabowski, U., von Clarmann, T., Stiller, G., Kellmann, S., Kiefer, M., Linden, A., Lossow, S. T. B., Bernath, P., Boone, C., Clerbaux, C., Degenstein, D., Fritz, S., Froidevaux, L., Hervig, M. K., Hoppel, J. L., McHugh, M., Sano, T., Sofieva, V., Suzuki, M., Tamminen, J., Urban, J., Walker, K., 
Weber, M., and Zawodny, J.: Validation of MIPAS IMK/IAA ozone profiles, Quadrenn. Ozone Symp., [online] available at: http://larss.science.yorku.ca/QOS2012pdf/5935.pdf, 2012.

Laeng, A., Hubert, D., Verhoelst, T., von Clarmann, T., Dinelli, B. M., Dudhia, A., Raspollini, P., Stiller, G., Grabowski, U., Keppens, A., Kiefer, M., Sofieva, V., Froideveaux, L., Walker, K. A., Lambert, J.-C. and Zehner, C.: The Ozone Climate Change Initiative: Comparison of four Level 2 Processors for the Michelson Interferometer for Passive Atmospheric Sounding (MIPAS), Remote Sens. Environ., submitted, 2013.

Lait, L. R.: An alternative form for potential vorticity, J. Atmos. Sci., 51, 1754-1759, doi:10.1175/15200469(1994)051<1754:AAFFPV>2.0.CO;2, 1994.

Mieruch, S., Weber, M., von Savigny, C., Rozanov, A., Bovensmann, H., Burrows, J. P., Bernath, P. F., Boone, C. D., Froidevaux, L., Gordley, L. L., Mlynczak, M. G., Russell III, J. M., Thomason, L. W., Walker, K. A., and Zawodny, J. M.: Global and long-term comparison of SCIAMACHY limb ozone profiles with correlative satellite data (2002-2008), Atmos. Meas. Tech., 5, 771-788, doi:10.5194/amt-5-771-2012, 2012.

Rahpoe, N., von Savigny, C., Weber, M., Rozanov, A.V., Bovensmann, H., and Burrows, J. P.: Error budget analysis of SCIAMACHY limb ozone profile retrievals using the SCIATRAN model, Atmos. Meas. Tech. Discuss., 6, 4645-4676, doi:10.5194/amtd-6-4645-2013, 2013.

Roth, C. Z., Degenstein, D. A., Bourassa, A. E., and Llewellyn, E. J.: The retrieval of vertical profiles of the ozone number density using Chappuis band absorption information and a multiplicative algebraic reconstruction technique, Can. J. Phys., 85, 12251243, doi:10.1139/P07-130, 2007.

Rozanov, A., Rozanov, V., and Burrows, J. P.: A numerical radiative transfer model for a spherical planetary atmosphere: combined differential-integral approach involving the Picard iterative approximation, J. Quant. Spectrosc. Ra., 69, 491-512, doi:10.1016/S0022-4073(00)00100-X, 2001

Rozanov, V. V., Rozanov, A. V., Kokhanovsky, A. A., and Burrows, J. P.: Radiative transfer through terrestrial atmosphere and ocean: Software package SCIATRAN, J. Quant. Spectrosc. Ra., doi:10.1016/j.jqsrt.2013.07.004, in press, 2013.

Sakazaki, T., Fujiwara, M., Mitsuda, C., Imai, K., Manago, N., Naito, Y., Nakamura, T., Akiyoshi, H., Kinnison, D., Sano, T., Suzuki, M., and Shiotani, M.: Diurnal ozone variations in the stratosphere revealed in observations from the Superconducting Submillimeter-Wave Limb-Emission Sounder (SMILES) on board the International Space Station (ISS), J. Geophys. Res.Atmos., 118, 2991-3006, doi:10.1002/jgrd.50220, 2013.

Sofieva, V. F., Tamminen, J., Haario, H., Kyrölä, E., and Lehtinen, M.: Ozone profile smoothness as a priori information in the inversion of limb measurements, Ann. Geophys., 22, 3411-3420, doi:10.5194/angeo-22-3411-2004, 2004.

Sofieva, V. F., Kan, V., Dalaudier, F., Kyrölä, E., Tamminen, J., Bertaux, J.-L., Hauchecorne, A., Fussen, D., and Vanhellemont, F.: Influence of scintillation on quality of ozone monitoring by GOMOS, Atmos. Chem. Phys., 9, 9197-9207, doi:10.5194/acp9-9197-2009, 2009.

Sofieva, V. F., Vira, J., Kyrölä, E., Tamminen, J., Kan, V., Dalaudier, F., Hauchecorne, A., Bertaux, J.-L., Fussen, D., Vanhellemont, F., Barrot, G., and Fanton d'Andon, O.: Retrievals from GOMOS stellar occultation measurements using characteriza- tion of modeling errors, Atmos. Meas. Tech., 3, 1019-1027, doi:10.5194/amt-3-1019-2010, 2010.

Sonkaew, T., Rozanov, V. V., von Savigny, C., Rozanov, A., Bovensmann, H., and Burrows, J. P.: Cloud sensitivity studies for stratospheric and lower mesospheric ozone profile retrievals from measurements of limb-scattered solar radiation, Atmos. Meas. Tech., 2, 653-678, doi:10.5194/amt-2-653-2009, 2009.

Tamminen, J., Kyrölä, E., Sofieva, V. F., Laine, M., Bertaux, J.-L., Hauchecorne, A., Dalaudier, F., Fussen, D., Vanhellemont, F., Fanton-d'Andon, O., Barrot, G., Mangin, A., Guirlet, M., Blanot, L., Fehr, T., Saavedra de Miguel, L., and Fraisse, R.: GOMOS data characterisation and error estimation, Atmos. Chem. Phys., 10, 9505-9519, doi:10.5194/acp-10-9505-2010, 2010.

Tegtmeier, S., Hegglin, M. I., Anderson, J., Bourassa, A., Brohede, S., Degenstein, D., Froidevaux, L., Fuller, R., Funke, B., Gille, J., Jones, A., Kasai, Y., Kyrölä, E., Lingenfelser, G., Lumpe, J., Nardi, B., Neu, J., D.Pendlebury, Remsberg, E., Rozanov, A., Smith, L., Toohey, M., Urban, J., Clarmann, T. von, Walker, K. A., and Wang, R.: SPARC Data Initiative: A comparison of ozone climatologies from international satellite limb sounders, J. Geophys. Res.-Atmos., 118, doi:10.1002/2013JD019877, 2013.

Toohey, M. and von Clarmann, T.: Climatologies from satellite measurements: the impact of orbital sampling on the standard error of the mean, Atmos. Meas. Tech., 6, 937-948, doi:10.5194/amt6-937-2013, 2013.

Urban, J., Lautié, N., Le Flochmoën, E., Jiménez, C., Eriksson, P., de La Noë, J., Dupuy, E., Ekström, M., El Amraoui, L., Frisk, U., Murtagh, D., Olberg, M., and Ricaud, P.: Odin/SMR limb observations of stratospheric trace gases: Level 2 processing of $\mathrm{ClO}$, $\mathrm{N}_{2} \mathrm{O}, \mathrm{HNO}_{3}$, and $\mathrm{O}_{3}$, J. Geophys. Res.-Atmos., 110, D14307, doi:10.1029/2004JD005741, 2005.

Urban, J., Murtagh, D., Lautié, N., Barret, B., Dupuy, E., de La Noë, J., Eriksson, P., Frisk, U., Jones, A., Le Flochmoë, E., Olberg, M., Piccolo, C., Ricaud, P., and Rösevall, J.: Odin/SMR Limb Observations of Trace Gases in the Polar Lower Stratosphere during 2004-2005, in: ESA Atmospheric Science Conference, 8-12 May 2006, Frascati, Italy, European Space Agency publications ESA-SP-628, ISBN: 92-9092-939-1, ISSN: 1609-042X., 2006.

von Clarmann, T., Glatthor, N., Grabowski, U., Höpfner, M., Kellmann, S., Kiefer, M., Linden, A., Mengistu Tsidu, G., Milz, M., Steck, T., Stiller, G. P., Wang, D. Y., Fischer, H., Funke, B., Gil-López, S., and López-Puertas, M.: Retrieval of temperature and tangent altitude pointing from limb emission spectra recorded from space by the Michelson Interferometer for Passive Atmospheric Sounding (MIPAS), J. Geophys. Res., 108, 4736, doi:10.1029/2003JD003602, 2003.

von Clarmann, T., Höpfner, M., Kellmann, S., Linden, A., Chauhan, S., Funke, B., Grabowski, U., Glatthor, N., Kiefer, M., Schieferdecker, T., Stiller, G. P., and Versick, S.: Retrieval of temperature, $\mathrm{H}_{2} \mathrm{O}, \mathrm{O}_{3}, \mathrm{HNO}_{3}, \mathrm{CH}_{4}, \mathrm{~N}_{2} \mathrm{O}, \mathrm{ClONO}_{2}$ and $\mathrm{ClO}$ from MIPAS reduced resolution nominal mode limb emission measurements, Atmos. Meas. Tech., 2, 159-175, doi:10.5194/amt-2-159-2009, 2009.

von Savigny, C., Kaiser, J. W., Bovensmann, H., Burrows, J. P., McDermid, I. S., and Leblanc, T.: Spatial and temporal characterization of SCIAMACHY limb pointing errors during the first three years of the mission, Atmos. Chem. Phys., 5, 2593-2602, doi:10.5194/acp-5-2593-2005, 2005a. 
von Savigny, C., Rozanov, A., Bovensmann, H., Eichmann, K.-U., Noël, S., Rozanov, V., Sinnhuber, B.-M., Weber, M., Burrows, J. P., and Kaiser, J. W.: The Ozone Hole Breakup in September 2002 as Seen by SCIAMACHY on ENVISAT, J. Atmos. Sci., 62, 721-734, doi:10.1175/JAS-3328.1, 2005b. 